\title{
Co-infection of two reoviruses increases both viruses accumulation in rice by up-regulating of viroplasm components and movement proteins bilaterally and RNA silencing suppressor unilaterally
}

\author{
Shu Li, Tong Zhang, Yingzhi Zhu and Guohui Zhou*
}

\begin{abstract}
Background: Synergism between southern rice black-streaked dwarf virus (SRBSDV) and rice ragged stunt virus (RRSV) not only aggravates disease symptoms but also enhances their vector acquisition efficiencies by increasing both viruses' titers in co-infected rice plants, which may exacerbate the epidemic of both viruses and cause significant damage to rice production. The molecular mechanism of viral synergism of these two viruses remains unexplored.

Methods: Single and double infection of SRBSDV and RRSV were obtained with the viruliferous white-backed planthopper and brown planthopper inoculation on four-leaf stage rice seedlings, respectively, under experimental condition. The second upper leaf from each inoculated rice plants were collected at 9, 15, and 20 days post inoculation (dpi) and used for relative quantification of 13 SRBSDV genes and 11 RRSV genes by the reverse-transcription quantitative PCR. Viral gene expression levels were compared between singly and doubly infected samples at the same stage.

Results: The movement protein and viroplasm matrix-related genes as well as the structural (capsid) protein genes of both viruses were remarkably up-regulated at different time points in the co-infected rice plants compared with the samples singly infected with SRBSDV or RRSV, however, the RNA silencing suppressor (P6) of only RRSV, but not of both the viruses, was up-regulated.

Conclusions: The SRBSDV-RRSV synergism promoted replication and movement of both viruses and inhibited the host immunity by enhancing the gene suppressing effect exerted by one of them (RRSV).
\end{abstract}

Keywords: Southern rice black-streaked dwarf virus, Rice ragged stunt virus, Co-infection, Synergism

\section{Background}

Southern rice black-streaked dwarf virus (SRBSDV) and Rice ragged stunt virus (RRSV) are members of Reoviridae family. SRBSDV is a novel species in genus Fijivirus and transmitted by the white-backed plant hopper (WBPH, Sogatella furcifera), while RRSV belongs to the genus Oryzavirus and is vectored by the brown plant hopper (BPH, Nilaparvata lugens); both vectors, the two major

\footnotetext{
* Correspondence: ghzhou@scau.edu.cn

Key Laboratory of Microbial Signals and Disease Control of Guangdong Province, College of Agriculture, South China Agricultural University, No 483 Wushan Road, Tianhe District, Guangzhou, Guangdong 510642, China
}

long-distance migratory rice pests in south and southeast Asia, transmit these viruses in a persistent, circulativepropagative manner $[1,2]$. SRBSDV was first discovered in China in 2001 and was identified in 2008 [3], and has become one of most important disease in southern china, northern Vietnam and Japan in recent years [4, 5]. RRSV was first described in Indonesia in 1977 [1] and reported in China in 1978 with only scattered distribution and occasional outbreaks [6]. However, RRSV occurrence became prominent recently with the co-infection of SRBSDV, probably due to elevated vector acquisition efficiency induced by the synergism of these two viruses [7]. 
The SRBSDV genome has ten linear double-stranded RNA (dsRNA) segments containing 13 open reading frames (ORFs), which putatively encode six structural proteins ( $\mathrm{P} 1$ to $\mathrm{P} 4, \mathrm{P} 8$ and $\mathrm{P} 10$ ) and seven nonstructural proteins (P5-1, P5-2, P6, P7-1, P7-2, P9-1 and P9-2). Based on the results analyzed by bioinformatics, the P1 is an RNA-dependent RNA polymerase (RdRP), P2 is a major core structural protein, P3 is an outer shell $\mathrm{B}$-spike protein, $\mathrm{P} 4$ is a capping protein, $\mathrm{P} 8$ is a minor core protein and P10 is a major outer-capsid protein [8]. P6 was identified as a viral RNA silencing suppressor (RSS) [9] and might participate in viroplasm formation with P5-1 and P9-1 $[10,11]$. P7-1 is the major component of the tubules and probably a viral movement protein (MP) [12]. The functions of P5-2, P7-2 and P9-2 remain unknown.

The RRSV genome contains ten dsRNA segments with 11 ORFs putatively encoding eight structural proteins (P1 to P3, P4a, P5, P8 and P9) and three non-structural proteins (P6, P7 and P10). Among the structural proteins, P1 is a major core structural protein and P2 has been reported to be a putative guanylyl transferase [13]. P3 is a capsid shell protein and P4a putatively functions as an RdRp [14]. P5 appears to be a guanyltransferase associated with $5^{\prime}$-capping in the processes of viral replication and transcription [15]. P8 has been identified as a major outer-capsid protein [16, 17]. P9 contributes as a spike protein refer to transmission by the insect vector [18]. Among the non-structural proteins of RRSV, P6 functions as a viral RSS and a MP [19], P7 is a NTPbinding protein [20] and P10 is a component of viroplasm [21]. The in vivo production and possible function of P4b is yet to be determined.

Our previous report found that synergism between SRBSDV and RRSV increased both virus titers in coinfected rice plants [7]. However, the molecular mechanism of viral synergism of the two viruses remains unexplored. In this study, we compared the expression levels of the viral genes between the rice plants singly infected with SRBSDV or RRSV and those with coinfection of both viruses at different disease stages using the reverse-transcription quantitative polymerase chain reaction (RT-qPCR). We found that compared with rice plants infected by SRBSDV or RRSV individually, the expression levels of some genes involved in SRBSDV and RRSV viroplasm formation were significantly up-regulated, and yet, of the RSSs of the two viruses, only P6 of RRSV was up-regulated, while some of the structural genes of both viruses were up-regulated. These findings suggest that synergism of SRBSDV and RRSV stimulates replication and movement of both viruses and weakens the host immunity through the RSS function of one of them, which result in an increase in both viruses' titers in doubly infected rice plants.

\section{Methods}

\section{Test plants, viruses, and insects}

The seeds of a rice cultivar 'Qiuyou-998' used in this research were maintained in our laboratory. The seeds were germinated by soaking in warm water, then sown in a plastic box sized $50 \mathrm{~cm}$ long, $25 \mathrm{~cm}$ wide and $8 \mathrm{~cm}$ high. The seedlings with uniform growth were individually transplanted into a culture tube half-filled with the nutrient solution culture $(\mathrm{pH} 4.5 \sim 5.0)$ when they were in the four-leaf stage [22]. The seedlings were allowed to grow in an incubator under the conditions of $28^{\circ} \mathrm{C}$ and $16 \mathrm{~h}$ light $/ 8 \mathrm{~h}$ dark.

The isolates of SRBSDV and RRSV were collected from diseased field in Guangzhou, Guangdong Province, China. Both isolates were transmitted to a number of Qiuyou-998 rice plants by WBPH and BPH, and grown in insect-proof greenhouses.

Five fourth-stage nymphs of WBPH or $\mathrm{BPH}$, which breed on SRBSDV or RRSV infected rice plants for two or three generations, were collected and then moved to each rice seedling at four-leaf stage. SRBSDV or RRSV singly infected rice plants were derived from rice seedlings inoculated with viruliferous WBPHs or BPHs, respectively, SRBSDV and RRSV co-infected rice plants were derived from rice seedlings inoculated with both viruliferous insects. At least 30 rice seedlings were used in each inoculation. All the insects were removed manually after a 24-h exposure. Second upper leaf from each inoculated rice plants were collected at 9,15 , and 20 days after the $24-\mathrm{h}$ insect exposure (days post inoculation, dpi), enclosed with aluminium foil paper, and put in a refrigerator of $-70{ }^{\circ} \mathrm{C}$ after liquid nitrogen freezing. SRBSDV or/and RRSV were detected in all inoculated rice plants at 20 dpi by RT-PCR using a One Step RNA PCR kit (AMV) (TaKaRa, Dalian, China) and specific primers for SRBSDV and RRSV according to Wang et al. [23]. Rice plants postitive for SRBSDV or RRSV and both viruses were defined as singly and coinfected rice plants. In total, 12 plants from each infection treatment were used for viral gene expression experiments.

\section{RT- qPCR detection}

Trizol RNAiso Plus (Invitrogen, Boston, MA) were used for total RNA extraction from frozen leaves from SRBSDV or RRSV singly or co-infected rice plants, and then treated with DNase I (TaKaRa). Spectrophotometry was used to determine the concentration and purity of the total RNA. Total RNA samples with $A_{260} / A_{280}$ and $\mathrm{A}_{260} / \mathrm{A}_{230}$ of 1.9 to 2.1 and greater than 2.0 , respectively, can be used as templates for RT-qPCR.

Primer Express (version 3.0; Applied Biosystems, Foster City, CA) was used to design the RT-qPCR primers (Table 1) based on 13 and 11 genes of SRBSDV and RRSV, respectively. The U6 small nuclear RNA gene of rice was used as a housekeeper or control genes for RT-qPCR (Table 1). 
Table 1 Reverse-transcription quantitative polymerase chain reaction primers used for quantification of southern rice black-streaked dwarf virus (SRBSDV) and rice ragged stunt virus (RRSV)

\begin{tabular}{|c|c|c|c|c|}
\hline Purpose & Gene name & Target gene (GenBank accession no.) & Primer for RT-qPCR(5'-3') & Size of expected amplicon (bp) \\
\hline \multirow[t]{24}{*}{ RRSV } & \multirow[t]{2}{*}{ RRSV P1 } & \multirow[t]{2}{*}{ HM125559 } & AGGATCTCTTCTCAATGCAAGC & \multirow[t]{2}{*}{70} \\
\hline & & & AACTTCCACCTGGCAACGTC & \\
\hline & \multirow[t]{2}{*}{ RRSV P2 } & \multirow[t]{2}{*}{ HM125560 } & GGCGTTCGATCTCGTGTTTAA & \multirow[t]{2}{*}{69} \\
\hline & & & GCGGGAAAATCATTGGCGTG & \\
\hline & \multirow[t]{2}{*}{ RRSV P3 } & \multirow[t]{2}{*}{ AF020336 } & TCAAAGCTAGTGATGAGCGTCTGT & \multirow[t]{2}{*}{70} \\
\hline & & & CTGGCATAAAAACGAAGAGTCTGA & \\
\hline & \multirow[t]{2}{*}{ RRSV P4A } & \multirow[t]{2}{*}{ HM125562 } & GGCGTCAGTGTGTAGCAGCAT & \multirow[t]{2}{*}{66} \\
\hline & & & ATTGGGTAGAGTTGTTGTTTTGGAT & \\
\hline & \multirow[t]{2}{*}{ RRSV P4B } & \multirow[t]{2}{*}{ HM125562 } & CGCCATCCACAAAGCTATCA & \multirow[t]{2}{*}{63} \\
\hline & & & AACACTCTCGTAGCCTGCCAAT & \\
\hline & \multirow[t]{2}{*}{ RRSV P5 } & \multirow[t]{2}{*}{ HM125562 } & CGCCATCCACAAAGCTATCA & \multirow[t]{2}{*}{59} \\
\hline & & & AACACTCTCGTAGCCTGCCAAT & \\
\hline & \multirow[t]{2}{*}{ RRSV S5 } & \multirow[t]{2}{*}{ HM125543 } & GGCGGCATCGGGTTGT & \multirow[t]{2}{*}{59} \\
\hline & & & CACCTCTATCAAACGCAGTAACCA & \\
\hline & \multirow[t]{2}{*}{ RRSV S6 } & \multirow[t]{2}{*}{ HM125554 } & GCTITCGCGGTGCTCAA & \multirow[t]{2}{*}{59} \\
\hline & & & СTCCCAATTACGCACCGAAT & \\
\hline & RRSV P7 & HM125555 & TGACGATTACGCCGAGACAAG & 62 \\
\hline & & & CGGACGACTGGCCAATG & \\
\hline & RRSV P8 & HM125546 & GGCTGAGCGTGCGGTTA & 66 \\
\hline & & & TCAGCCTTGATATCGTTGTAGCA & \\
\hline & RRSV P9 & L79969 & GGTGTGGCTCTACAACAAATGG & 67 \\
\hline & & & ACGCCTCTITCTCTGCTCCTCTA & \\
\hline & RRSV P10 & HM125568 & CCGAGCCGCCATCATAGTA & 63 \\
\hline & & & ACCTCAAAAACTCCAGACAGCATA & \\
\hline SRBSDV & SRBSDV P1 & JQ692572 & TGTGATTTGAACTCAGAGACAGCTTAA & 80 \\
\hline & & & TGACGTTGATAAGTTGATTGTTGAGA & \\
\hline & SRBSDV P2 & HM585278 & GCGAACGGCTTTCTGCTTT & 71 \\
\hline & & & GAATGTGCGAGTGATTTCATGAA & \\
\hline & SRBSDVP3 & HM585277 & TCCCGGTGTTCGAGAAGTTC & 64 \\
\hline & & & CAGCATTTTCCATCCAACCAT & \\
\hline & SRBSDV P4 & HM585276 & TCAACGCTCGACAACCAAAA & 72 \\
\hline & & & TTATCGTGATATCTGCTACGAATACCA & \\
\hline & SRBSDV P5-1 & HM585275 & ATCAGATGATAACCTCAATCGTACCA & 94 \\
\hline & & & TGAGCCAGTGAAGGTAATCATCATTA & \\
\hline & SRBSDV P5-2 & & CGCTTAACAATTGTCGTGATATGAA & 75 \\
\hline & & & GCGTGCTTCCGAAAAGTAAAGTT & \\
\hline & SRBSDV P6 & HM585274 & AAGCAACAAACATCAACGTCAAA & 69 \\
\hline & & & AACTACGTCGGCCCATGAAC & \\
\hline & SRBSDV P7-1 & HM58527 & CCTAATGAAAACCCATCTACCTGTAAC & 70 \\
\hline & & & CACGAATAAACATCAGCGACAAA & \\
\hline & SRBSDV P7-2 & & CAAATATTAGTAGAAGCAGAACGCAAGT & 61 \\
\hline & & & ACATCTTITTCGTCTTTCTCATACTCTTAA & \\
\hline
\end{tabular}


Table 1 Reverse-transcription quantitative polymerase chain reaction primers used for quantification of southern rice black-streaked dwarf virus (SRBSDV) and rice ragged stunt virus (RRSV) (Continued)

\begin{tabular}{|c|c|c|c|c|}
\hline \multirow{2}{*}{\multicolumn{2}{|c|}{ SRBSDV P8 }} & \multirow[t]{2}{*}{ HM585272 } & GATTGTCTCCTTTGGATGATGTTG & \multirow[t]{2}{*}{72} \\
\hline & & & CCTGTCCTTCTTGAAATACACGTAAC & \\
\hline & \multirow[t]{2}{*}{ SRBSDV P9-1 } & \multirow[t]{2}{*}{ HM585271 } & TGAAAGCGAATCCTCAACTAAAGA & \multirow[t]{2}{*}{68} \\
\hline & & & TTGAATCAGTGGAGGTGGGTT & \\
\hline & \multirow[t]{2}{*}{ SRBSDV P9-2 } & & CGAGATGAGCGATTCTGGTTT & \multirow[t]{2}{*}{70} \\
\hline & & & TTCGTGAATGATGTTGTTAACCTITT & \\
\hline & \multirow[t]{2}{*}{ SRBSDV P10 } & \multirow[t]{2}{*}{ EU784840 } & TCATCATTAGCGCGACTAGTTCA & \multirow[t]{2}{*}{64} \\
\hline & & & CGTCACTCGGCGTCGATAA & \\
\hline \multirow[t]{2}{*}{ Reference } & \multirow[t]{2}{*}{ U6 } & \multirow[t]{2}{*}{ S83742 } & CGATAAAATTGGAACGATACAGA & \multirow[t]{2}{*}{72} \\
\hline & & & ATTTGGACCATTTCTCGATTTGT & \\
\hline
\end{tabular}

A PrimeScript RT reagent kit (TaKaRa) was used to reverse-transcribed the total RNA into cDNA. cDNA were synthesized using $2 \mu \mathrm{L}$ of $5 \times$ RT buffer, $0.5 \mu \mathrm{L}$ of RT Enzyme Mix I, $0.5 \mu \mathrm{L}$ of oligo dT, $6 \mu \mathrm{L}$ of RNasefree double-distilled $\left(\mathrm{ddH}_{2} \mathrm{O}\right)$, and $2 \mu \mathrm{g}$ total RNA, the reaction was conducted at $42{ }^{\circ} \mathrm{C}$ for $15 \mathrm{~min}$ followed by $95{ }^{\circ} \mathrm{C}$ for $2 \mathrm{~min}$. The qPCR was performed on a Cycler Dice Real Time System TP800 (TaKaRa) using 2 ng of cDNA, $0.5 \mu \mathrm{L}$ each of the forward and reverse primers $(10 \mu \mathrm{M}), 12.5 \mu \mathrm{L}$ of SYBR Premix Ex Taq II, and 9.5 of RNase-free $\mathrm{dd}_{2} \mathrm{O}$. The reactions were run for $95{ }^{\circ} \mathrm{C}$ for $30 \mathrm{~s}$, followed by 40 cycles of $95{ }^{\circ} \mathrm{C}$ for $5 \mathrm{~s}$ and $60{ }^{\circ} \mathrm{C}$ for 30 s. No-template reaction that replacing cDNA with RNase-free ddH2O was used as negative control and the U6 small nuclear RNA gene of rice was used as a housekeeper or control genes for all detections. A 10-fold gradient dilution of cDNA was used to construct a dissolution curve and a relative standard curve for determining the specificity and amplification efficiency of each primer. All primers had a single peak for dissolution curve and exhibited $90 \%$ to $110 \%$ amplification efficiency in all reactions. Analysis of relative genes expression data using $2-\Delta \Delta \mathrm{Ct}$ method. At least six rice plants were used for each treatment, and each reaction was run in triplicate.

\section{Statistical analysis}

The statistical software package SPSS 19.0 (IBM, Armonk, $\mathrm{NY)}$ was used to analyze the experimental data. A $t$-test with Bonferroni correction was used to compare gene relative expression levels in different treatment at the same stage.

\section{Results}

The expression levels of genes involved in the formation of viroplasms of both viruses were significantly up-regulated in SRBSDV and RRSV co-infected rice

The expression levels of three genes involved in the formation of SRBSDV viroplasms (P5-1, P6 and P9-1) were compared between SRBSDV singly infected and coinfected rice plants. No significant difference in the expression levels of P5-1 at 9 dpi was found between SRBSDV-infected rice plants and those co-infected with RRSV, but P5-1 was up-regulated 1.44 times at $15 \mathrm{dpi}$ $(F=3.442$, df $=6, P=0.583)$ and 1.15 times at $20 \mathrm{dpi}$ $(F=1.229, \mathrm{df}=6, P=0.064)$ in co-infected plants. The expression of P9-1 was significantly up-regulated at all three tested disease progression time points; 1.62 times at $9 \mathrm{dpi}(F=2.307, \mathrm{df}=10, P=0.003), 1.32$ times at 15 dpi $(F=1.628, \mathrm{df}=8, P=0.002)$ and 1.23 times at 20 dpi $(F=0.905, \mathrm{df}=10, P=0.006)$. The expression levels of $\mathrm{P} 6$ showed no significant changes at any of the tested time points (Fig. 1).

The expression levels of three genes involved in viroplasm formation of RRSV (P3, P6 and P10) were compared in RRSV-infected and co-infected rice plants. The expression of P3 was up-regulated 1.29 times at $9 \mathrm{dpi}$ $(F=0.342, \mathrm{df}=10, P=0.592), 1.53$ times at $15 \mathrm{dpi}$ $(F=2.286, \mathrm{df}=8, P=0.020)$ and 1.34 times at $20 \mathrm{dpi}$

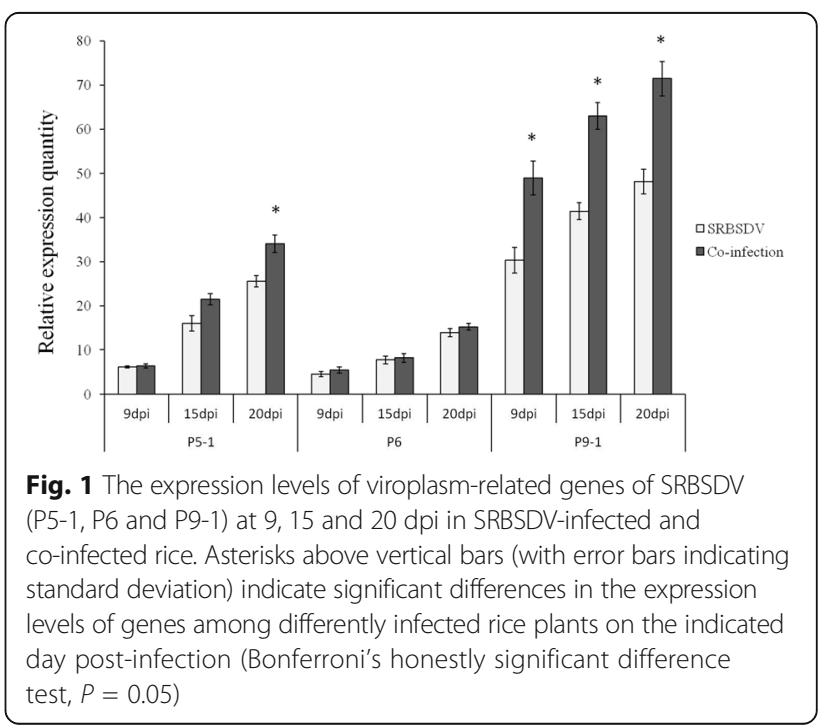


( $F=0.132, \mathrm{df}=8, P=0.050)$. The expression of $\mathrm{P} 6$ was significantly up-regulated at all three tested disease progression time points; 1.43 times at $9 \mathrm{dpi}$ $(F=0.456, \mathrm{df}=10, P=0.018), 1.7$ times at $15 \mathrm{dpi}$ $(F=0.407, \mathrm{df}=10, P=0.001)$, and 1.29 times at $20 \mathrm{dpi}$ $(F=0.132, \mathrm{df}=10, P<0.001)$. The expression level of $\mathrm{P} 10$ was also up-regulated at all three time points, 1.16 times at 9 dpi $(F=0.314$, df $=10, P=0.114), 1.25$ times at $15 \mathrm{dpi}(F=1.026$, df $=10, P<0.000)$, and 1.19 times at 20 dpi $(F=0.004$, df $=10, P=0.098)$, in co-infected plants (Fig. 2).

\section{The expression level of viral RSS gene of RRSV was unilaterally up-regulated in SRBSDV and RRSV co-infected rice}

The P6 proteins of SRBSDV and RRSV have been identified as the RSSs of these two viruses $[12,19]$. No significant difference in the expression levels of SRBSDV P6 was found between SRBSDV-infected plants and those co-infected with RRSV at any of the tested disease progression time points (Fig. 1). However, the expression level of RRSV P6 was significantly up-regulated at 9, 15 and $20 \mathrm{dpi}$ (Fig. 1).

\section{The expression levels of viral MP genes of both SRBSDV and RRSV were up-regulated in SRBSDV and RRSV co-infected rice}

P7-1 of SRBSDV was previously determined to be a viral MP [12]. It was up-regulated at all three tested time points in SRBSDV and RRSV co-infected plants. At 9 dpi, it was slightly up-regulated $(F=4.738, \mathrm{df}=10$, $P=0.126)$, but at $15 \mathrm{dpi}$ and $20 \mathrm{dpi}$, it was significantly up-regulated by 1.92 times $(F=1.937, \mathrm{df}=10$, $P=0.010)$ and 1.23 times $(F=8.571, \mathrm{df}=10, P<0.001)$, respectively, in co-infected rice compared with SRBSDV singly infected rice (Fig. 3). P6 of RRSV was also

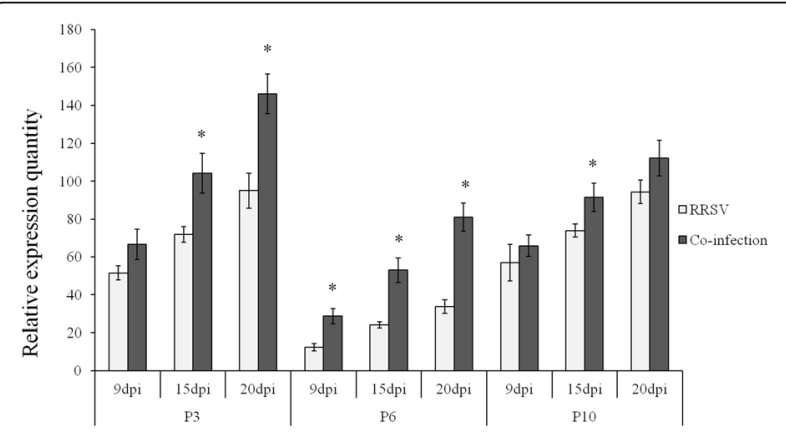

Fig. 2 The expression levels of viroplasm-related genes of RRSV (P3, P6 and P10) at 9, 15 and 20 dpi in RRSV-infected and co-infected rice. Asterisks above vertical bars (with error bars indicating standard deviation) indicate significant differences in the expression levels of genes among differently infected rice plants on the indicated day post-infection (Bonferroni's honestly significant difference test, $P=0.05$ )

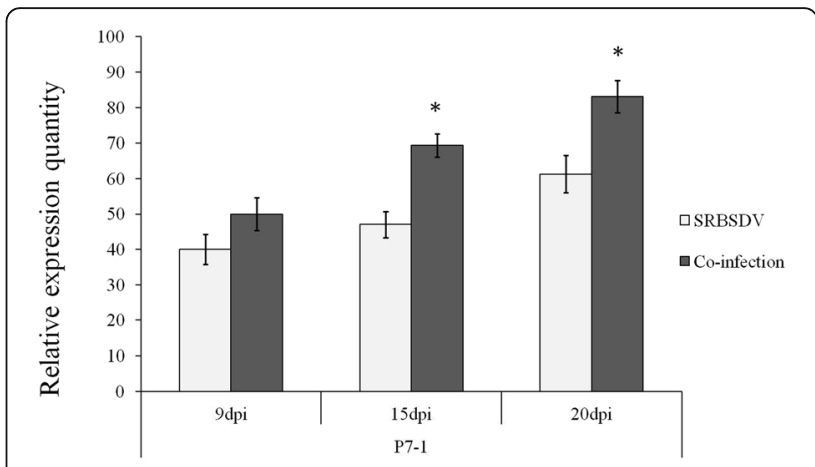

Fig. 3 The expression levels of movement protein (MP) genes of SRBSDV (P7-1) at 9, 15 and 20 dpi in SRBSDV-infected and co-infected rice. Asterisks above vertical bars (with error bars indicating standard deviation) indicate significant differences in the expression levels of genes among differently infected rice plants on the indicated day post-infection (Bonferroni's honestly significant difference test, $P=0.05$ )

indentified as a viral MP [19], and it was significantly upregulated at 9, 15 and 20 dpi in co-infected rice (Fig. 2).

\section{The expression levels of viral CPs of both SRBSDV and RRSV were unilaterally up-regulated in SRBSDV and RRSV co-infected rice}

Compared with SRBSDV or RRSV single infection, the expression levels of all structural protein genes of both SRBSDV and RRSV were up-regulated to various degrees in co-infected plants (Additional file 1: Figure S1 and Additional file 2: Figure S2). Among them, changes in the expression levels of SRBSDV P10 and RRSV P8 reached statistically significant level (Fig. 4). SRBSDV P10 was slightly up-regulated at $9 \mathrm{dpi}(F=0.420, \mathrm{df}=10$, $P=0.085)$ and significantly up-regulated 2.06 times at 15 dpi $(F=1.116, \mathrm{df}=10, P=0.029)$ and 1.43 times at 20 dpi $(F=13.658$, df $=10, P=0.004)$ in co-infected plants. RRSV P8 was significantly up-regulated at all three tested disease progression time points, 1.44 times at $9 \mathrm{dpi}(F=0.005$, df $=16, P=0.040), 1.76$ times at $15 \mathrm{dpi}$ $(F=2.442, \mathrm{df}=26, P<0.001)$, and 1.41 times at $20 \mathrm{dpi}$ $(F=0.132, \mathrm{df}=8, P=0.050)$, in co-infected plants (Fig. 4).

\section{Discussion}

SRBSDV and RRSV, which are both in the family Reoviridae, have for the past few years caused serious rice disease in eastern and southeastern Asia. Our prior studies have shown that there is a synergistic interaction between SRBSDV and RRSV [7]. Rice plants co-infected with both viruses display aggravated symptoms, while the titers of both viruses and the acquisition efficiencies of both vectors are increased, which is of great epidemiological importance. However, there has not been sufficient research on the mechanism of synergistic interaction between plant viruses in the same family. Hence, we studied the expression levels of all genes of 

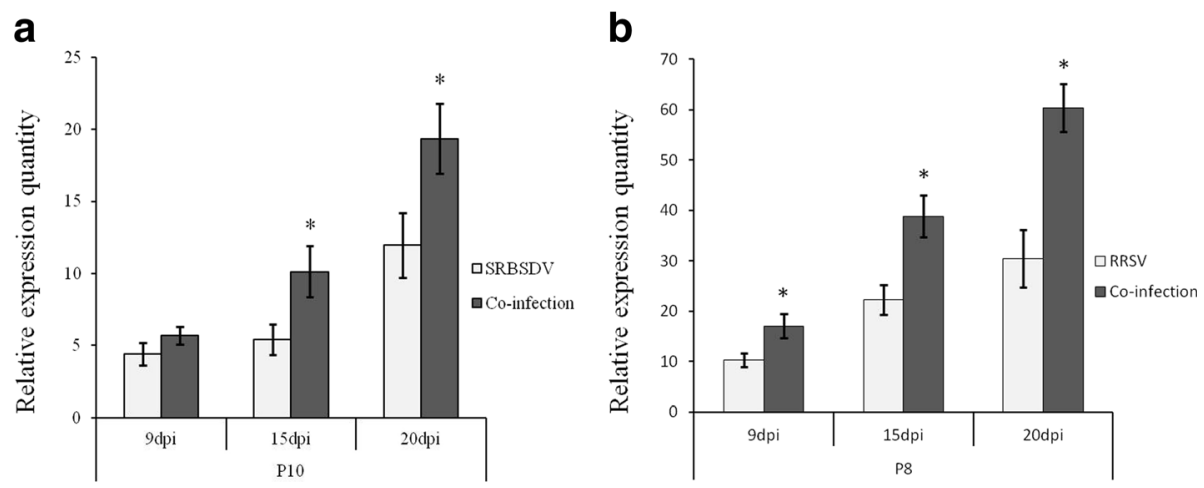

Fig. 4 The expression levels of viral coat protein (CP) genes of SRBSDV (P10) (a) and RRSV (P8) (b) at 9, 15 and 20 dpi in SRBSDV- or RRSV-infected and co-infected rice. Asterisks above vertical bars (with error bars indicating standard deviation) indicate significant differences in the expression levels of genes among differently infected rice plants on the indicated day post-infection (Bonferroni's honestly significant difference test, $P=0.05$ )

SRBSDV and RRSV at three representative stages of the disease course (9,15 and $20 \mathrm{dpi})$, in order to expand our knowledge of the synergistic interaction between two viruses in the same family.

On the basis of previous research, SRBSDV is a dsRNA virus, $3^{\prime}$ end of the genome lacks poly-A tail [3]. In this research, the single-stranded cDNA templates of 13 genes of SRBSDV and 11 genes of RRSV were simultaneously synthesized using oligo-dT anchor primers according to $\mathrm{He}$ et al. [24], to avoid confusion between the virus genomes and transcripts.

The expression levels of P5-1, P7-1, P9-1 and P10 of SRBSDV and P3, P6, P8 and P10 of RRSV were significantly up-regulated in co-infected rice. These upregulated genes include some genes associated with the formation of the viral factory (viroplasm) matrix (P5-1 and P9-1 of SRBSDV and P3, P6 and P10 of RRSV) $[10,11,14,19,21]$, viral MPs (P7-1 of SRBSDV and P6 of RRSV) [12,19] and viral CPs (P10 of SRBSDV and P8 of RRSV) [3, 17]. These up-regulated genes may play crucial roles in the synergism between SRBSDV and RRSV, and their upregulation also shows that co-infection increased both virus titers and facilitated the replication and movement of both viruses, which is consistent with our previous research [7].

RNA silencing functions as an antiviral defense response to virus genome expression, replication, and movement in plants, likewise, plant virus generally encode RSS to suppress host silencing that enable virus establish systemic infection in plants $[25,26]$. Some research have shown that the function of viral RSSs often involved in synergism of plant virus [25-29]. Interestingly, the P6 proteins of SRBSDV and RRSV have been identified as the RSSs of these two viruses $[9,19]$, but only the expression level of protein P6 of RRSV was significantly up-regulated in co-infected plants. This unilateral influence mechanism is related to different silencing effects of the two viruses RSSs or effects in different nodes of the RNAi pathway. Thus, whether P6 of RRSV mediates the synergism between SRBSDV and RRSV and its possible mechanism deserve further study.

Compared with SRBSDV or RRSV single infection, most of the genes involved in viroplasm formation of SRBSDV and RRSV were significantly up-regulated in co-infected plants. Previous studies have shown that P6 of SRBSDV can interact with itself and P5-1, and might format the viroplasm by recruiting P9-1 [10, 11]. For RRSV, P10 is essential for viroplasm formation and virus replication; it can recruit P6 into viroplasm-like structures when these two proteins are co-expressed in Sf9 cells [21]. This study showed that the genes involved in viroplasm formation were up-regulated in co-infected plants; from another perspective, it proves that the replication levels of both viruses were enhanced. Importantly, however, the upregulation pattern of viroplasm-related genes varied in timing. At 9 dpi, only P9-1 of SRBSDV and P6 of RRSV were significantly up-regulated in co-infected plants, suggesting that these two genes might be the main limiting factors at the initial stage of viroplasm formation; viroplasms began to form only if the expression of these two genes reached a critical level. The expression of the other genes was significantly up-regulated at 15 or $20 \mathrm{dpi}$, suggesting that different genes become important at different stages of the formation and expansion of the viroplasm. In addition, the genes up-regulated at different times are likely to improve the interaction between the viroplasm-related genes, thereby enhancing the replication efficiency of the two viruses in co-infected plants.

Increasing amounts of experimental evidence show that, although MPs of different plant virus share lower sequence homology, they are functional commonalities. Consequently, the viral MPs of distinct species, and even distinct genus, can complement movement deficiency of each other and mediate the systemic movement and synergism of heterologous viruses [30-32]. P7-1 of SRBSDV and P6 of RRSV are recognized as viral MPs $[12,19]$. 
These genes were significantly up-regulated at 9, 15 and 20 dpi in co-infected plants, which may facilitate the movement and spread of the two viruses, thereby exacerbating the symptoms of co-infected rice plants.

In this study, we found that the expression of viroplasm-related genes, the MP and $\mathrm{CP}$ genes were significantly up-regulated in the co-infected rice plants, but the expression levels of the other viral genes were not significantly affected by co-infection (Additional file 1 : Figure S1, Additional file 2: Figure S2, Additional file 3: Figure S3 and Additional file 4: Figure. S4). It may indicate that the enhanced virion replication happens at low expression levels of these other genes.

\section{Conclusions}

Compared with the samples singly infected with SRBSDV or RRSV, the viral movement protein and viroplasm matrixrelated genes as well as the structural (capsid) protein genes of the two viruses were remarkably up-regulated bilaterally at different time points in the co-infected rice plants, while the RNA silencing suppressor (P6) of only RRSV, but not of both the viruses, was up-regulated. We therefore proposed that the SRBSDV-RRSV synergism promoted replication and movement of both the viruses and inhibited the host immunity by enhancing the gene suppressing effect exerted by one of them (RRSV), leading to an increase of both viruses' titers in the co-infected rice plants.

\section{Additional files}

Additional file 1: Figure S1. The expression levels of structural protein genes of SRBSDV (P1 to P4, P8 and P10) at 9, 15 and 20 dpi in SRBSDV-infected and co-infected rice. Besides P10, which was significantly up-regulated (Fig. 4), the remaining genes were slightly up-regulated at 9, 15 and $20 \mathrm{dpi}$ in co-infected plants. Vertical bars correspond to error bars indicating standard deviation (Bonferroni's honestly significant difference test, $P=0.05)$. (JPEG $300 \mathrm{~kb}$ )

Additional file 2: Figure S2. The expression levels of structural protein genes of RRSV (P1 to P5, P8 and P9) at 9, 15 and 20 dpi in RRSV-infected and co-infected rice. Besides P3 at 15 and 20 dpi (Fig. 2), and P8 at 9, 15 and $20 \mathrm{dpi}$ (Fig. 4), which were significantly up-regulated, the remaining genes were slightly up-regulated at 9, 15 and $20 \mathrm{dpi}$ in co-infected plants. Vertical bars correspond to error bars indicating standard deviation (Bonferroni's honestly significant difference test, $P=0.05)$. (JPEG $309 \mathrm{~kb}$ )

Additional file 3: Figure S3. The expression levels of non-structural protein genes of SRBSDV (P5-1, P5-2, P7-1, P7-2, P9-1 and P9-2) at 9, 15 and 20 dpi in SRBSDV-infected and co-infected rice. Besides P5-1 at 15 dpi (Fig. 1), P7-1 at 15 and 20 dpi (Fig. 3) and P9-1 at 9, 15 and 20 dpi (Fig. 1), which were significantly up-regulated, the remaining genes were slightly up-regulated at 9, 15 and 20 dpi in co-infected plants. Vertical bars correspond to error bars indicating standard deviation (Bonferroni's honestly significant difference test, $P=0.05$ ). (JPEG $225 \mathrm{~kb}$ )

Additional file 4: Figure S4. The expression levels of non-structural protein genes of RRSV (P6, P7 and P10) at 9, 15 and 20 dpi in RRSV-infected and co-infected rice. P7 was slightly up-regulated at 9, 15 and $20 \mathrm{dpi}$, while P6 at 9, 15 and $20 \mathrm{dpi}$, and P10 at $15 \mathrm{dpi} \mathrm{(Fig.} \mathrm{2)} \mathrm{were} \mathrm{significantly}$ up-regulated in co-infected plants. Vertical bars correspond to error bars indicating standard deviation (Bonferroni's honestly significant difference test, $P=0.05)$. (JPEG $203 \mathrm{~kb})$

\section{Abbreviations}

BPH: Brown planthopper; CP: Capsid protein; Dpi: Days post inoculation; dsRNA: double stranded RNA; MP: Movement protein; ORF: Open reading frame; RdRp: RNA-dependent RNA polymerase; RRSV: Rice ragged stunt virus; RSS: RNA silencing suppressor; RT-qPCR: Reverse transcription-quantitative PCR; SRBSDV: Southern rice black-streaked dwarf virus; WBPH: White-backed planthopper

\section{Acknowledgements}

We thank Jingxian Xue for her excellent work in growth chamber and lab maintenance.

\section{Funding}

This research was supported by the National Natural Science Foundation of China (31272012) and the Special Fund for Agroscientific Research in the Public Interest of China (201303021).

Availability of data and materials Not applicable.

\section{Authors' contributions}

GZ conceived and designed the experiments and revised the manuscript. SL performed the experiments, analyzed the data, and wrote the draft. TZ and $\mathrm{YZ}$ prepared the material, analyzed the data and revised the manuscript. All authors read and approved the final manuscript.

Ethics approval and consent to participate Not applicable.

\section{Consent for publication}

Not applicable.

\section{Competing interests}

The authors declare that they have no competing interests.

\section{Publisher's Note}

Springer Nature remains neutral with regard to jurisdictional claims in published maps and institutional affiliations.

Received: 7 March 2017 Accepted: 4 August 2017

Published online: 08 August 2017

\section{References}

1. Hibino H, Roechan M, Sudarisman S, Tantera DM. A virus disease of rice (Kerdil hampa) transmitted by brown planthopper, Nilaparvata lugens Stal in Indonesia. Contr Centr Res Inst Agric. 1977;35:1-15.

2. Pu LL, Xie GH, Ji CY, Ling B, Zhang MX, Xu DL, Zhou GH. Transmission characters of Southern rice black-streaked dwarf virus by rice planthoppers. Crop Prot. 2012;41:71-6.

3. Zhou GH, Wen JJ, Cai DJ, Li P, Xu DL, Zhang SG. Southern rice black-streaked dwarf virus: a new proposed Fijivirus species in the family Reoviridae. Chin Sci Bull. 2008;53:3677-85.

4. Zhou GH, Xu DL, Xu DG, Zhang MX. Southern rice black-streaked dwarf virus: a white-backed planthopper-transmitted fijivirus threatening rice production in Asia. Front Microbiol. 2013;4:270. doi:10.3389/fmicb.2013.00270.

5. Matsukura K, Towata T, Sakai J, Onuki M, Okuda M, Matsumura M. Dynamics of Southern rice black-streaked dwarf virus in rice and implication or virus acquisition. Phytopathology. 2013;103:509-12.

6. Zhou LG, Du JY, Li XR, Cao L. Research on the Rice ragged dwarf virus in Guangdong. J Guangdong Agric Sci. 1982;3:31-4.

7. Li S, Wang H, Zhou GH. Synergism between Southern rice black-streaked dwarf virus and Rice ragged stunt virus enhances their insect vector acquisition. Phytopathology. 2014;104:794-9.

8. Wang Q, Yang J, Zhou GH, Zhang HM, Chen JP, Adams MJ. The complete genome sequence of two isolates of Southern rice black-streaked dwarf virus, a new fijivirus. J Phytopathol. 2010;158:733-7.

9. Lu YH, Zhang JF, Xiong RY, Xu QF, Zhou YJ. Identification of an RNA silencing suppressor encoded by Southern rice black- streaked dwarf virus S6. Sci Agric Sin. 2011;44:2909-17. 
10. Li J, Xue J, Zhang HM, Yang J, Lv MF, Xie L. Interactions between the P6 and P5- 1 proteins of southern rice black- streaked dwarf fijivirus in yeast and plant cells. Arch Virol. 2013;158:1649-59.

11. Mao Q, Zheng S, Han Q, Chen H, Ma Y, Jia D, Chen Q, Wei T. New model for the genesis and maturation of viroplasms induced by fijiviruses in insect vector cells. J Virol. 2013:87:6819-28.

12. Liu Y, Jia D, Chen H, Chen Q, Xie L, Wu Z, Wei T. The P7-1 protein of Southern rice black-streaked dwarf virus, a fijivirus, induces the formation of tubular structures in insect cells. Arch Virol. 2011;156:1729-36.

13. Supyani S, Hillman Bl, Suzuki N. Baculovirus expression of the 11 mycoreovirus-1 genome segments and identification of the guanylyltransferase-encoding segment. J Gen Virol. 2007;88:342-50.

14. Upadhyaya NM, Ramm K, Gellatly JA, Li Z, Kositratana W, Waterhouse PM. Rice ragged stunt oryzavirus genome segment $\$ 4$ could encode an RNA dependent RNA polymerase and a second protein of unknown function. Arch Virol. 1998;143:1815-22.

15. Li Z, Upadhyaya NM, Kositratana W, Gibbs AJ, Waterhouse PM. Genome segment 5 of rice ragged stunt virus encodes a virion protein. J Gen Virol. 1996;77:3155-60.

16. Hagiwara K, Minobe Y, Nozu Y, Hibino H, Kimura I, Omura T. Component proteins and structures of rice ragged stunt virus. J Gen Virol. 1986;67:1711-5.

17. Upadhyaya NM, Zinkowsky E, Li Z, Kositratana W, Waterhouse PM. The Mr 43K major capsid protein of rice ragged stunt oryzavirus is a post-translationally processed product of a Mr 67,348 polypeptide encoded by genome segment 8. Arch Virol. 1996;141:1689-701.

18. Zhou GY, Lu XB, Lu HJ, Lei JL, Chen SX, Gong ZX. Rice ragged stunt oryzavirus: role of the viral spike protein in transmission by the insect vector. Ann Appl Biol. 1999;135:573-8.

19. Wu J, Du Z, Wang C, Cai L, Hu M, Lin Q, Wu Z, Li Y, Xie L. Identification of Pns6, a putative movement protein of RRSV, as a silencing suppressor. Virol J. 2010;7:1-6.

20. Upadhyaya NM, Ramm K, Gellatly JA, Li Z, Kositratana W, Waterhouse PM. Rice ragged stunt oryzavirus genome segments S7 and S10 encode non-structural proteins of Mr 68,025 (Pns7) and Mr 32,364 (Pns10). Arch Virol. 1997;142:1719-26.

21. Jia DS, Guo NM, Chen HY, Akita F, Xie LH, Omura T, Wei TY. Assembly of the viroplasm by viral non-structural protein Pns10 is essential for persistent infection of rice ragged stunt virus in its insect vector. J Gen Virol. 2012;93:2299-309.

22. Yoshida S, Forno DA, Gomez KA. Laboratory manual for physiological studies of rice. 3rd ed. Manila, Philippines: International Rice Research Institute; 1976. p. 61-4.

23. Wang $H, X u$ DL, Pu LL, Zhou GH. Southern rice black-streaked dwarf virus alters insect vectors' host orientation preferences to enhance spread and increase Rice ragged stunt virus coinfection. Phytopathology. 2014;104:196-201.

24. He P, Liu JJ, He M, Wang ZC, Chen Z, Guo R, Correll JC, Yang S, Song BA Quantitative detection of relative expression levels of the whole genome of Southern rice black-streaked dwarfvirus and its replication in different hosts. Virol J. 2013;10:136. doi:10.1186/1743-442X-10-136.

25. Alvarado $V$, Scholthof HB. Plant responses against invasive nucleic acids: RNA silencing and its suppression by plant viral pathogens. Semin Cell Dev Biol. 2009;20:1032-40.

26. Dunoyer $P$, Voinnet $O$. The complex interplay between plant viruses and host RNA-silencing pathways. Curr Opin Plant Biol. 2005;8:415-23.

27. Pruss G, Ge X, Shi XM, Carrington JC, Vance VB. Plant viral synergism: the potyviral genome encodes a broad-range pathogenicity enhancer that transactivates replication of heterologous viruses. Plant Cell. 1997;9:859-68.

28. Srinivasan $R$, Alvarez JM. Effect of mixed viral infections (Potato virus Y-Potato leaf roll virus) on biology and preference of vectors Myzus persicae and Macrosiphum euphorbiae (Hemiptera: Aphididae). J Econ Entomol. 2007;100:646-55.

29. Takeshita M, Koizumi M, Noguchi M, Sueda K, Shimura H, Ishikawa N, Matsuura H, Ohshima K, Natsuaki T, Kuwata S, Furuya N, Tsuchiya K, Masuta C. Infection dynamics in viral spread and interference under the synergism between Cucumber mosaic virus and Turnip mosaic virus. Mol Plant-Microbe Interact. 2011;25:18-27.

30. Atabekov JG, Taliansky ME. Expression of a plant virus-coded transport function by different viral genomes. Adv Virus Res. 1990;38:201-48.
31. Ryabov EV, Robinson DJ, Taliansky ME. A plant virus-encoded protein facilitates long-distance movement of heterlogous RNA. Proc Natl Acad Sci U S A. 1999;96:1212-7.

32. Tomenius K. Function and localisation of movement proteins of Tobacco mosaic virus and Red clover mottle virus. NATO ASI series H: Cell biology; 1990. p. 249-59.

\section{Submit your next manuscript to BioMed Central and we will help you at every step:}

- We accept pre-submission inquiries

- Our selector tool helps you to find the most relevant journal

- We provide round the clock customer support

- Convenient online submission

- Thorough peer review

- Inclusion in PubMed and all major indexing services

- Maximum visibility for your research

Submit your manuscript at www.biomedcentral.com/submit

) Biomed Central 